\title{
Engineered endophytic bacteria improve phytoremediation of water-soluble, volatile, organic pollutants
}

\author{
Tanja Barac ${ }^{1}$, Safiyh Taghavi ${ }^{2,3}$, Brigitte Borremans ${ }^{2}$, Ann Provoost $^{2}$, Licy Oeyen ${ }^{1}$, Jan V Colpaert ${ }^{1}$, \\ Jaco Vangronsveld ${ }^{1} \&$ Daniel van der Lelie ${ }^{2,3}$
}

\begin{abstract}
Phytoremediation of highly water soluble and volatile organic xenobiotics is often inefficient because plants do not completely degrade these compounds through their rhizospheres. This results in phytotoxicity and/or volatilization of chemicals through the leaves, which can cause additional environmental problems. We demonstrate that endophytic bacteria equipped with the appropriate degradation pathway improve the in planta degradation of toluene. We introduced the pTOM toluene-degradation plasmid of Burkholderia cepacia G4 into B. cepacia L.S.2.4, a natural endophyte of yellow lupine. After surface-sterilized lupine seeds were successfully inoculated with the recombinant strain, the engineered endophytic bacteria strongly degraded toluene, resulting in a marked decrease in its phytotoxicity, and a $50-70 \%$ reduction of its evapotranspiration through the leaves. This strategy promises to improve the efficiency of phytoremediating volatile organic contaminants.
\end{abstract}

Emerging phytoremediation technologies have been applied at various scales to treat moderately hydrophobic pollutants, such as benzene, toluene, ethylbenzene and xylene (BTEX) compounds, chlorinated solvents, nitrotoluene ammunition wastes and excess nutrients ${ }^{1}$. Phytoremediation of organic xenobiotics is based on interactions between plants and their associated microorganisms in a process whereby plants draw pollutants, including polyaromatic hydrocarbons (PAHs), into their rhizosphere via the transpiration stream ${ }^{2}$; subsequently, microorganism-mediated degradation occurs in the plant itself, in the rhizosphere or in both.

The fate of the contaminant in the rhizosphere-root system largely depends on its physicochemical properties. Organic xenobiotics with a $\log \mathrm{K}_{\mathrm{ow}}$ (octanol/water partition coefficient $)<1$ are considered to be very water-soluble, and plant roots do not generally accumulate them at a rate surpassing passive influx into the transpiration stream ${ }^{3}$. Contaminants with a $\log \mathrm{K}_{\mathrm{ow}}>3.5$ show high sorption to the roots, but slow or no translocation to the stems and leaves ${ }^{4}$. However, plants readily take up organic xenobiotics with a $\log \mathrm{K}_{\mathrm{ow}}$ between 0.5 and 3.5 , as well as weak electrolytes (weak acids and bases or amphoteres as herbicides). These compounds seem to enter the xylem faster than the soil and rhizosphere microflora can degrade them, even if the latter is enriched with degrading bacteria ${ }^{5}$. Once taken up, plants metabolize these contaminants, although some of them, or their metabolites, such as trichloroethene (TCE), which is transformed into trichloro acetic acid, can be toxic ${ }^{6}$. Alternatively, plants preferentially release volatile pollutants, such as BTEX compounds and TCE and their metabolites, into the environment by evaporation via the leaves, which calls into question the merits of phytoremediation ${ }^{7-10}$. There is thus a need for different strategies to improve the phytoremediation of such contaminants.

In this study we aimed to increase the degradation of volatile, watersoluble organic contaminants during their transport in the plant's vascular system using engineered endophytic bacteria. Endophytic bacteria reside within the living tissue of a plant without substantively harming it ${ }^{11,12}$. They are ubiquitous in most plant species, residing latently or actively colonizing the tissues. Bacterial endophytes are highly diverse with many different taxa colonizing a wide variety of plant species ${ }^{13}$. It has been reported ${ }^{14}$ that substantial numbers of endophytes $\left(10^{3}-10^{6}\right.$ cells) can colonize the vascular system (phloem, xylem). The highest densities usually are observed in the roots and decrease progressively from the stem to the leaves.

In this study we demonstrate that a genetically modified endophytic strain of B. cepacia, whose host plant is the yellow lupine (Lupinus luteus L.), improves in planta degradation and reduces evapotranspiration of toluene, a moderately hydrophobic $\left(\log \mathrm{K}_{\mathrm{ow}}=2.69\right.$ at $\left.20^{\circ} \mathrm{C}\right)$ volatile compound.

\section{RESULTS}

Inoculation of yellow lupine with $\boldsymbol{B}$. cepacia

We chose yellow lupine as our plant model. B. cepacia BU0072 (refs. 15,16), which is derived from the endophytic strain B. cepacia L.S.2.4, and its toluene-degrading derivative VM1330, were used to inoculate

${ }^{1}$ Limburgs Universitair Centrum (LUC), Department of Environmental Biology, Universitaire Campus building D, B-3590 Diepenbeek, Belgium. ${ }^{2}$ Flemish Institute for Technological Research (VITO), Environmental Technology Expertise Center, Boeretang 200, B-2400 Mol, Belgium. ${ }^{3}$ Brookhaven National Laboratory (BNL), Biology Department, Building 463, Upton, New York 11973-5000, USA. Correspondence should be addressed to D.v.d.L. (vdlelied@bnl.gov). 
Table 1 Growth characteristics and number of bacterial colonies isolated from roots and shoots of L. Iuteus plants

\begin{tabular}{lllccc}
\hline Inoculum $^{\mathrm{a}}$ & Plant part & $284+$ gluc $^{\mathrm{b}}$ & $284+\mathrm{Ni}+\mathrm{Km}+\mathrm{gluc} \mathrm{c}^{\mathrm{b}}$ & $284+\mathrm{Ni}+\mathrm{Km}+$ tol $^{\mathrm{b}}$ & $2^{284+\text { tol }^{\mathrm{b}}}$ \\
\hline No & Shoot & $2.3 \times 10^{2}(2)^{\mathrm{c}}$ & 0 & 0 & 0 \\
No & Root & $1.7 \times 10^{3}(3)$ & 0 & 0 & 0 \\
VM1330 & Shoot & $6.9 \times 10^{3}(1)$ & $3.8 \times 10^{2}(1)$ & $5.8 \times 10^{2}(1)$ & $4.3 \times 10^{2}(1)$ \\
VM1330 & Root & $9.5 \times 10^{3}(1)$ & $2.2 \times 10^{2}(1)$ & $1.7 \times 10^{2}(1)$ & $1.9 \times 10^{2}(1)$ \\
BU0072 & Shoot & $1.3 \times 10^{4}(2)$ & $2.2 \times 10^{2}(1)$ & 0 & 0 \\
BU0072 & Root & $1.5 \times 10^{3}(3)$ & $1.5 \times 10^{3}(1)$ & 0 & 0 \\
G4 & Shoot & $5.7 \times 10^{4}(2)$ & 0 & 0 & $1.0 \times 10^{4}(1)$ \\
G4 & Root & $7.8 \times 10^{4}(2)$ & 0 & 0 & $1.5 \times 10^{2}(1)$ \\
\hline
\end{tabular}

a L. Iuteus plants were inoculated with B. cepacia strains VM1330, BU0072 and G4. As controls, plants without inoculum were analyzed. ${ }^{b} \mathrm{Ni}: 1 \mathrm{mM}$ nickel; $\mathrm{Km}: 100 \mu \mathrm{g} / \mathrm{ml}$ kanamycin; tol: toluene vapor as C-source; gluc: gluconate as C-source. ${ }^{\mathrm{C}}$ The number of bacteria was determined $21 \mathrm{~d}$ after inoculation. The number of bacteria is expressed per $\mathrm{g}$ fresh weight. Data are the average of three experiments. Numbers in parentheses are the numbers of different morphological types of bacteria as observed visually.
As expected, bacteria isolated from the shoots and roots of yellow lupine inoculated with VM1330 $\left(\mathrm{Km}^{\mathrm{R}}, \mathrm{Ni}^{\mathrm{R}}, \mathrm{Tol}^{+}\right)$grew on all three selective media. Plants inoculated with BU0072 $\left(\mathrm{Km}^{\mathrm{R}}, \mathrm{Ni}^{\mathrm{R}}, \mathrm{Tol}^{-}\right)$harbored no toluene-degrading bacteria. From plants inoculated with strain $\mathrm{G} 4\left(\mathrm{Tol}^{+}\right)$, isolated bacteria grew on a medium containing toluene, but only in the absence of nickel and kanamycin.

Using Repetitive Extragenic Palindromic (REP)-PCR we demonstrated that the bacteria isolated on the selective media had the same genetic fingerprints as B. cepacia G4, BU0072 and VM1330, respectively (results not shown). In addition, the presence of nre (strain BU0072), pTOM (strain G4), and both nre the plant. Both are resistant to kanamycin and nickel. In addition, we tested the endophytic characteristics of the toluene-degrading soil bacterium B. cepacia G4.

Twenty-one days after inoculating the bacteria, the plants were harvested; roots and shoots were separated, surface-sterilized, rinsed and macerated. The total numbers of specific bacteria in the crushed materials, as well as their specific growth characteristics (resistance properties and toluene degradation) were determined on different selective media (Table 1). The number of CFUs (colony forming units) was calculated per gram of fresh weight of roots or shoots. We found that three weeks after inoculation, all three B. cepacia strains could be isolated from yellow lupine. For control plants without inoculum, no bacteria were found on the selective media, except on nonselective medium $(284+$ glucose $)$, demonstrating that despite surface sterilization of the seeds, endogenous endophytic bacteria remained in the plants.

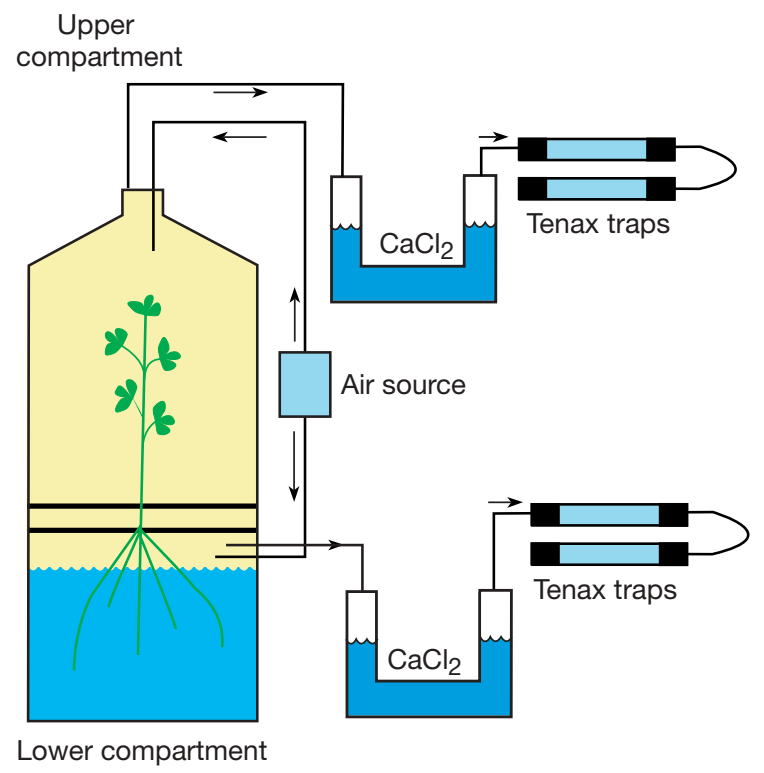

Figure 1 Schematic representation of the experimental setup for measuring toluene evapotranspiration. Yellow lupine plants are grown as hydroponics in a two-compartment glass cuvette system. Continuous airflow allows toluene from the gas phases from both compartments to collect on Tenax traps. A $\mathrm{CaCl}_{2}$-filled column was installed to prevent condensation of water in the Tenax traps. Tenax traps were cooled with dry ice to optimize adsorption capacities. and PTOM (strain VM1330) was determined by PCR, confirming that the three strains had colonized the plants. Bacteria isolated from the control plants showed a different REP-PCR pattern from strains BU0072, G4 and VM1330. These endophytic bacteria, which were also found after inoculation with B. cepacia BU0072 and G4, were further characterized and found to belong to typical endophytic and rhizosphere-colonizing species. Based on their REP-PCR patterns, five distinct species were found and these were identified by the sequence of their 16S rDNA: (i) Paenibacillus sp., a typical plant-associated, nitrogen-fixing bacterium of the rhizosphere, which has been found as an endophyte in plants as diverse as pine and potato ${ }^{17,18}$; (ii) Bacillus megaterium, (iii) Pantoea sp. and (iv) a Pseudomonas sp., which all have been reported to be endophytic bacteria in pea $^{19}$, a member of the Fabaceae, like yellow lupine; and (v) a Bacillus novalis sp. nov., which was recently isolated from the Drentse A grasslands ${ }^{20}$. None of these bacteria was able to grow on toluene as a carbon source.

\section{Selective enrichment of endophytic bacteria by toluene}

We investigated how the presence and concentration of toluene affected colonization by the bacteria. Earlier results had indicated that growing plants on contaminated soil could selectively enhance the prevalence of endophytes containing the degradation pathways for specific pollutants ${ }^{21}$. After $21 \mathrm{~d}$ of growth without toluene, the plants were transferred to glass cuvettes containing toluene in the lower compartment at final concentrations of $0,100,500$ or 1,000 mg/l. After $96 \mathrm{~h}$ the plants were harvested, and their shoots and roots examined for endophytic colonization. Samples and dilutions of $100 \mu \mathrm{l}$ were plated on different media. We could not discern a clear effect of the toluene concentration on the efficiency of colonization by different endophytic strains, and therefore, differences in the toluene-degradation properties of the inoculated plants will not reflect differences in the density of the endophytic population. An average of $10^{5}-10^{6} \mathrm{CFU}$ per gram fresh weight was found, and as in the experiment described in Table 1, growth on selective media was observed only after plants had been inoculated with the appropriate strains. Strain G4 was, in general, the most efficient colonizer of yellow lupine $\left(10^{6} \mathrm{CFU}\right.$ per gram fresh weight compared to $10^{5} \mathrm{CFU}$ for BU0072 and VM1330). In addition, the same endogenous endophytic bacteria were found in the control plants after surface sterilization.

\section{Effect on plant growth during hydroponic cultivation}

We examined the effect of toluene on the hydroponic growth of plants inoculated with B. cepacia VM1330, BU0072 or G4 and compared it with the effect on noninoculated controls. The experiments were car- 


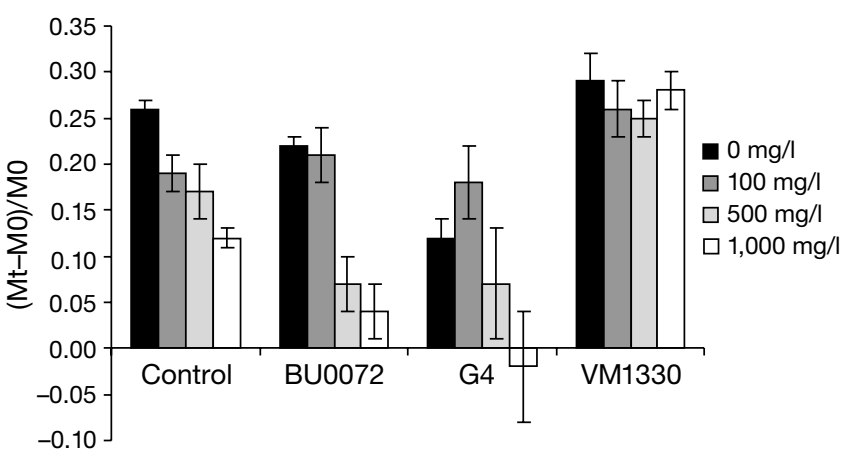

Figure 2 Difference in biomass (g) between inoculated and control yellow lupine plants, before and after adding toluene. Plants were grown as hydroponics in the glass cuvette system described in Figure 1. Noninoculated control plants and lupine plants inoculated with B. cepacia strains VM1330, BU0072 and G4 were used. M0, plant weight (g) before addition of toluene; Mt, plant weight (g) $96 \mathrm{~h}$ after toluene addition. The concentrations of toluene were $0,100,500$ and 1,000 mg/l, respectively. Standard deviations are indicated as bars. The statistical significance of the results was confirmed at the $5 \%$ level using a two-way ANOVA model, separately exploring treatment (bacterial inocula) and toluene doses.

ried out in the glass cuvette system schematically presented in Figure 1. The growth indices were calculated as the difference in plant's fresh weight between the onset of the experiment and after $96 \mathrm{~h}$ exposure to different concentrations of toluene. In the absence of toluene, plants inoculated with $B$. cepacia $\mathrm{G} 4$ produced significantly $(P=0.05)$ less biomass than the control plants and those inoculated with $B$. cepacia BU0072 and VM1330 (Fig. 2). This indicates that high numbers of the environmental B. cepacia $\mathrm{G} 4$ strain, which is not known to be a natural endophyte of yellow lupine, has a negative effect on plant development.

For plants and bacteria incubated in the presence of toluene, the growth indices suggested that increasing levels of toluene resulted in greater phytotoxicity (Fig. 2). However, plants inoculated with the endophytic strain B. cepacia VM1330, which can efficiently metabolize toluene, showed no difference in growth compared to controls without toluene. Even at concentrations of 1,000 mg/l toluene in the growth medium, these plants showed no signs of phytotoxicity, in contrast to the control plants that experienced phytotoxicity at levels above $100 \mathrm{mg} / \mathrm{l}$. This shows that strain VM1330 efficiently assists its host plant in overcoming toluene's phytotoxicity. Plants inoculated with B. cepacia BU0072 and G4 show phytotoxicity to toluene that is similar to that of the noninoculated control plants, suggesting that the combination of natural endophytic behavior plus the presence of the toluene degradation capacity is required to protect the plant. The statistical significance of the results was confirmed at the 5\% level using a twoway ANOVA model, separately exploring treatment (bacterial inocula) and toluene doses.

\section{Toluene degradation and evapotranspiration}

After adding toluene at a sub-phytotoxic concentration of $100 \mathrm{mg} / \mathrm{l}$, we measured the amount of toluene that is evapotranspired through the aerial parts of the plant (upper compartment) as well as its disappearance from Hoagland's nutrient solution (lower compartment) using gas chromatography/mass spectrometry (GC-MS) (Fig. 3).

Compared to control plants and plants inoculated with B. cepacia BU0072 or G4, those inoculated with B. cepacia VM1330 released 50-70\% less toluene in the upper compartment (Fig. 3). This result shows that this toluene-degrading endophytic strain not only protects

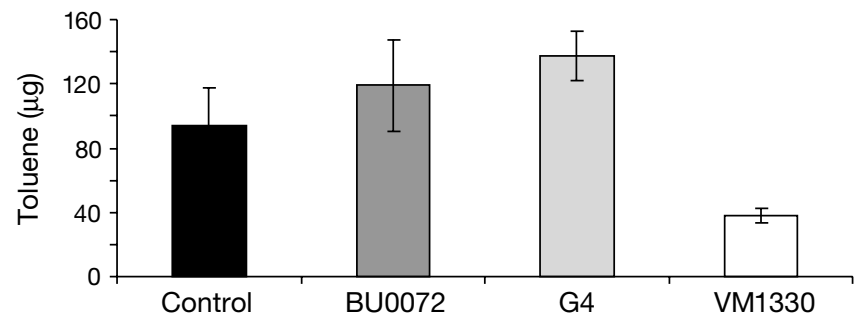

Figure 3 Total amount of toluene $(\mu \mathrm{g})$ detected in Tenax traps connected with the upper compartment (containing the aerial part of L. luteus plant) determined by GC-MS. For this experiment, noninoculated control plants and lupine plants inoculated with B. cepacia strains VM1330, BU0072 and G4 were used. The statistical significance of the results was confirmed at the $5 \%$ level using a one-way ANOVA model.

its host plant against phytotoxicity, but also significantly $(P=0.05)$ lowers toluene evapotranspiration through the aerial parts, even at levels that are not toxic to control plants. No significant $(P=0.05)$ differences in the concentrations of evapotranspired toluene were observed between plants inoculated with BU0072 or G4, and the noninoculated controls. The statistical significance of the reduced toluene release in the presence of strain VM1330 was confirmed at the $5 \%$ level using a one-way ANOVA model.

To further examine the fate of the toluene, we also analyzed the amount that evaporated from the Hoagland's solution in the gasphase of the lower compartment. The smallest amount of evaporated toluene, 2,523 $( \pm 853) \mu \mathrm{g}$, was obtained from plants inoculated with B. cepacia VM1330, compared to $3,378( \pm 987) \mu \mathrm{g}, 4,362( \pm 733) \mu \mathrm{g}$ and 7,367 $( \pm 298) \mu \mathrm{g}$ for the control plants and the plants inoculated with BU0072 or G4, respectively. These results show that together the endophytic strain B. cepacia VM1330 and its host plant, yellow lupine, improve the degradation of toluene, lowering both its phytotoxicity and release by evapotranspiration.

\section{Effect on plant growth during greenhouse studies}

We further examined the protective effect of the endophytic strain B. cepacia VM1330 on its host plant in greenhouse studies growing the plants on a nonsterile sandy soil. It is clear that control plants suffer from phytotoxic effects when irrigated for two weeks with water that contains toluene at a concentration of $100 \mathrm{mg} / \mathrm{l}$, and that they cannot survive higher toluene concentrations (Figs. 4 and 5). Inoculation of yellow lupine with B. cepacia BU0072 had a slightly positive effect, as it reduced toluene phytotoxicity in the group treated with $100 \mathrm{mg} / \mathrm{l}$. Plants exposed to the higher toluene concentrations died within one week. Inoculation with the toluene-degrading B. cepacia G4 strain resulted in a partial reduction of toluene phytotoxicity, which can be explained by degradation of toluene in the rhizosphere. A clear protective effect of B. cepacia VM1330 was observed on the growth of yellow lupine at all toluene concentrations tested, including the $500 \mathrm{mg} / \mathrm{l}$ doses. The statistical significance of the results was confirmed at the 5\% level using a two-way ANOVA model, separately exploring treatment (bacterial inocula) and toluene doses. These results confirm our hypothesis that endophytic bacteria, when equipped with the appropriate degradation pathway, can help plants survive under conditions of elevated levels of toluene.

\section{DISCUSSION}

In this paper we describe how an engineered endophytic bacterium can improve the phytoremediation of an organic contaminant. We 


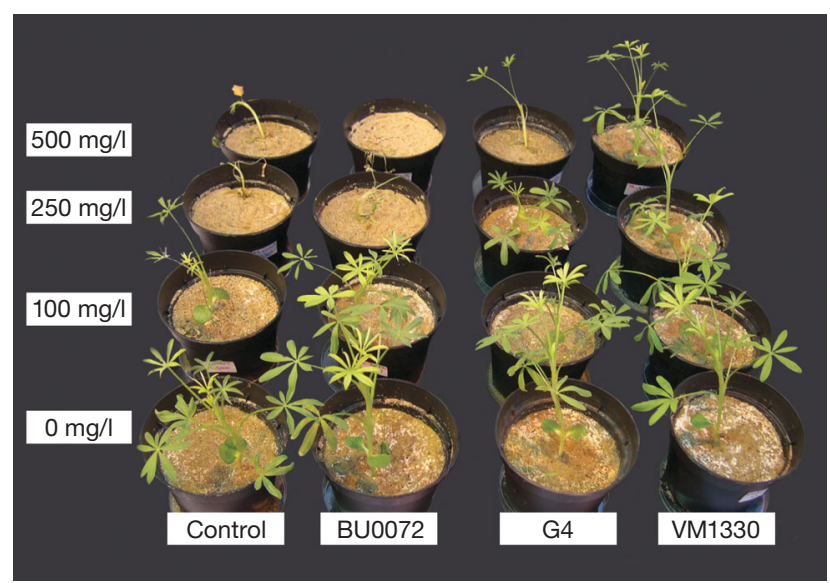

Figure 4 Phytotoxic effect of toluene on yellow lupine grown in nonsterile sandy soil under the greenhouse conditions. The labels indicate the control plants and lupine plants inoculated with B. cepacia strains VM1330, BU0072 and G4. Plants were irrigated every other day with half-strength Hoagland's solution to which toluene was added at concentrations of 0 , 100,250 and $500 \mathrm{mg} / \mathrm{l}$. A picture of representative plants was taken after $14 \mathrm{~d}$ of irrigation with toluene-containing solutions.

demonstrate that an endophytic bacterium equipped with the appropriate degradation pathway not only protects its host plant against the phytotoxic effect of an environmental contaminant, but also improves the overall degradation of the contaminant, resulting in its decreased evapotranspiration to the environment.

The protective effect of the endophytic bacteria was demonstrated for plants grown either as hydroponics or in nonsterile soil under greenhouse conditions. The results also show that the presence of B. cepacia VM1330, a toluene-degrading endophyte, provides much better protection against the phytotoxic effects of toluene than that obtained when the rhizosphere of the plant is inoculated with B. cepacia G4, a toluene-degrading soil bacterium (Figs. 4 and 5).

The introduction of the pTOM plasmid into B. cepacia BU0072, which resulted in strain B. cepacia VM1330, was done through natural gene transfer (conjugation). Although for practical purposes we used a marked recipient strain, which allows us to monitor the colonization of yellow lupine, this experiment can easily be repeated using a naturallyoccurring endophytic recipient, such as B. cepacia L.S.2.4, and an autotrophic mutant of $B$. cepacia G4. Accordingly, the transconjugants obtained by conjugation using a naturally occurring endophytic recipient should not be considered genetically modified microorganisms (GMO), a factor that may facilitate their application and public acceptance. It will be relatively straightforward to construct, by natural gene transfer, a collection of endophytic bacteria with a la carte degradation properties because many endophytic bacteria are closely related to environmental strains that carry degradation pathways for a broad spectrum of organic xenobiotics on mobile DNA elements. For example, we are constructing derivatives of B. cepacia L.S.2.4 that constitutively express the tomA toluene-ortho-monooxygenase of pTOM $^{22,23}$. This strain will be applied to improve the phytoremediation-based containment of TCE-contaminated groundwater plumes. Other applications we envisage include the use of engineered endophytic bacteria to degrade pesticide and herbicide residues in crop plants, addressing important food safety related issues.

The next step will be to expand and apply the work at various levels to poplar (Populus sp.) and willow (Salix sp.) to phytoremediate

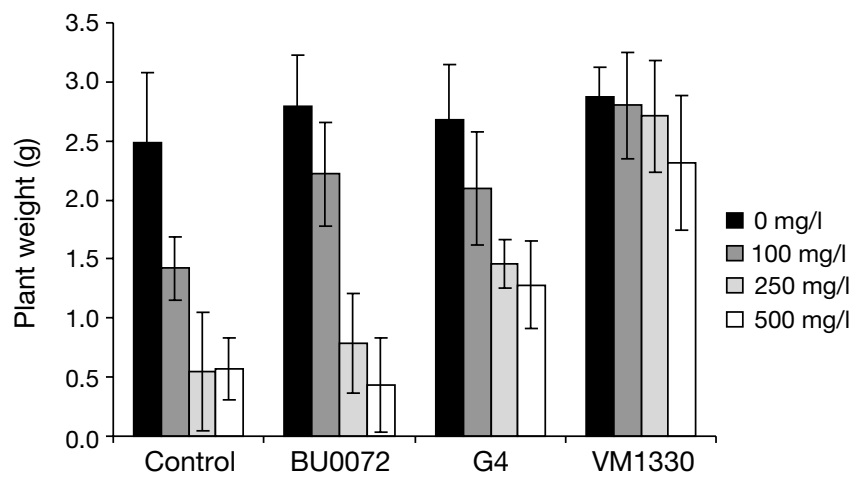

Figure 5 Biomass (g) of yellow lupine plants, grown in nonsterile sandy soil under the greenhouse conditions, after 14-d exposure to the different toluene concentrations. For this experiment, noninoculated control plants and lupine plants inoculated with B. cepacia strains VM1330, BU0072 and G4 were used. Plants were irrigated every other day with half-strength Hoagland's solution to which toluene was added at concentrations of 0, 100, 250 and $500 \mathrm{mg} / \mathrm{l}$. Standard deviations are indicated as bars. The statistical significance of the results was confirmed at the $5 \%$ level using a two-way ANOVA model, separately exploring treatment (bacterial inocula) and toluene doses.

groundwater contaminated with water-soluble organics. A collection of approximately 150 different endophytic bacteria from poplar and willow is available, and these strains have been identified and characterized (F. Porteous Moore, T.B., B.B., L.O., C.D. Campbell, J.V., D.v.d.L. and E.R.B. Moore, unpublished data). We have also shown the inoculation of poplar with a GFP-marked endophytic Pseudomonas sp., demonstrating the generalizability of the approach ${ }^{24}$. We can reasonably hypothesize that endophytic bacteria, possessing the genetic information required to efficiently degrade an organic contaminant, promote its breakdown as it moves through the plant's vascular system. In trees, the time between the uptake of the pollutant by the roots and its arrival in the leaves can take several hours to days ${ }^{25}$, allowing sufficient time for efficient degradation by endophytic bacteria in the xylem.

We expect that the application of genetically engineered endophytic bacteria will become a general strategy to improve the efficiency of phytoremediating volatile organic contaminants and other water soluble organic xenobiotics, and that the technique will gain regulatory and public acceptance.

\section{METHODS}

Construction of a toluene-degrading endophyte. B. cepacia strain BU0072 $\left(\mathrm{Ni}^{\mathrm{R}}, \mathrm{Km}^{\mathrm{R}}\right)$, a derivative of the endophytic bacterium B. cepacia L.S.2.4, was used $^{15,16}$. B. cepacia G4 $\left(\text { pTOM, } \mathrm{Tol}^{+}\right)^{26}$ served as a donor strain for toluene degradation. After conjugation ${ }^{16}$, transconjugants that were resistant to nickel plus kanamycin and could grow on toluene as sole carbon source were selected on ' 284 ' minimal medium ${ }^{27}$ supplemented with $1 \mathrm{mM} \mathrm{NiCl}_{2}$ plus $100 \mu \mathrm{g} / \mathrm{ml}$ kanamycin, while the plates were incubated under a toluene atmosphere to provide the carbon source. The 284 medium contains per liter distilled water: $6.06 \mathrm{~g}$ Tris- $\mathrm{HCl}$, $4.68 \mathrm{~g} \mathrm{NaCl}, 1.49 \mathrm{~g} \mathrm{KCl}, 1.07 \mathrm{~g} \mathrm{NH}_{4} \mathrm{Cl}, 0.43 \mathrm{~g} \mathrm{NaSO}_{4}, 0.20 \mathrm{~g} \mathrm{MgCl}_{2}$. $6 \mathrm{H}_{2} \mathrm{O}, 0.03 \mathrm{~g} \mathrm{CaCl}_{2} \cdot 2 \mathrm{H}_{2} \mathrm{O}, 40 \mathrm{mg} \mathrm{Na} 2 \mathrm{HPO}_{4} \cdot 2 \mathrm{H}_{2} \mathrm{O}, 10 \mathrm{ml} \mathrm{Fe}(\mathrm{III}) \mathrm{NH}_{4}$ citrate solution (containing $48 \mathrm{mg} / 100 \mathrm{ml}$ ), $1 \mathrm{ml}$ microelements solution, final pH 7. A carbon source, such as gluconate, is added at $0.2 \%(\mathrm{wt} / \mathrm{vol})$. The microelement solution contains per liter distilled water: $1.3 \mathrm{ml} \mathrm{25 \%} \mathrm{HCl}, 144 \mathrm{mg} \mathrm{ZnSO}$

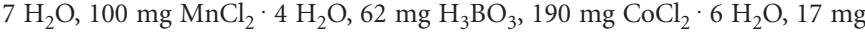
$\mathrm{CuCl}_{2} \cdot 2 \mathrm{H}_{2} \mathrm{O}, 24 \mathrm{mg} \mathrm{NiCl}_{2} \cdot 6 \mathrm{H}_{2} \mathrm{O}$ and $36 \mathrm{mg} \mathrm{NaMoO}{ }_{4} \cdot 2 \mathrm{H}_{2} \mathrm{O}$. The presence of the nre Ni resistance marker and the pTOM plasmid in the transconjugants 
was confirmed with PCR using nre and pTOM specific primers, respectively. A representative transconjugant, B. cepacia strain VM1330, which had the correct genetic makeup and grew under the appropriate selective conditions with toluene as sole carbon source, was selected for further studies.

The stability of the pTOM plasmid in VM1330 was verified by growing the strain for 100 generations on nonselective 284 gluconate minimal medium in the absence of toluene. Then, 100 individual colonies were selected on nonselective medium, and subsequently replica-plated on 284 minimal medium supplemented with $1 \mathrm{mM} \mathrm{NiCl} 2$ plus $100 \mu \mathrm{g} / \mathrm{ml}$ kanamycin, while the plates were incubated under a toluene atmosphere to provide the carbon source. All colonies tested thrived, demonstrating the stability of the toluene-degradation properties located on the pTOM plasmid (less than $1 \%$ loss of the plasmid after growth for 100 generations under nonselective conditions), as well as the other resistance markers.

Inoculation of yellow lupine with B. cepacia. B. cepacia VM1330 was grown in 284 gluconate medium $(250 \mathrm{ml}$ culture $)$ at $22^{\circ} \mathrm{C}$ on a rotary shaker for approximately $7 \mathrm{~d}$ until a density of $10^{+9} \mathrm{CFU} / \mathrm{ml}$ was reached $\left(\mathrm{OD}_{660}\right.$ of 1$)$. The cells were collected by centrifugation, washed twice in $10 \mathrm{mM} \mathrm{MgSO}_{4}$ and suspended in $1 / 10$ of the original volume $10 \mathrm{mM} \mathrm{MgSO}_{4}$ to obtain an inoculum with a cell density of $10^{10} \mathrm{CFU} / \mathrm{ml}$.

Seeds of $L$. luteus $L$. were surface-sterilized for $30 \mathrm{~min}$ at $20^{\circ} \mathrm{C}$ in a solution containing $1 \%$ active chloride ( $\mathrm{wt} / \mathrm{vol}$, added as a $\mathrm{NaOCl}$ solution) and 1 droplet Tween 80 per $100 \mathrm{ml}$ solution. The seeds then were rinsed three times for $1 \mathrm{~min}$ in sterile water and dried on sterile filter paper. To test the efficiency of sterilization, the seeds were incubated for $3 \mathrm{~d}$ at $30{ }^{\circ} \mathrm{C}$ on 869 medium ${ }^{28}$, which contains per liter distilled water: $10 \mathrm{~g}$ tryptone, $5 \mathrm{~g}$ yeast extract, $5 \mathrm{~g} \mathrm{NaCl}, 1 \mathrm{~g}$ D-glucose, $0.345 \mathrm{~g} \mathrm{CaCl}_{2} \cdot 2 \mathrm{H}_{2} \mathrm{O}$ ( $\mathrm{pH}$ 7). Seeds were considered sterile when no bacterial growth was observed. Five surface sterile seeds of $L$. luteus $L$. were planted in a sterile plastic jar $(800 \mathrm{ml})$, completely filled with sterilized perlite and saturated with $400 \mathrm{ml}$ of a half-strength sterile Hoagland's nutrient solution. Subsequently, the bacterial inoculum was added to each jar at a final concentration of $10^{8} \mathrm{CFU} / \mathrm{ml}$ Hoagland's solution (three Hoagland's stock solutions are prepared; solution 1: macroelements, containing $102 \mathrm{~g} \mathrm{KNO}_{3}$, $70.8 \mathrm{~g} \mathrm{Ca}\left(\mathrm{NO}_{3}\right)_{2} \cdot 4 \mathrm{H}_{2} \mathrm{O}, 23 \mathrm{~g} \mathrm{NH}_{4} \mathrm{H}_{2} \mathrm{PO}_{4}, 49 \mathrm{~g} \mathrm{MgSO}_{4} \cdot 7 \mathrm{H}_{2} \mathrm{O}$ per 10 liters distilled water; solution 2: Fe solution containing $1.9 \mathrm{~g} \mathrm{FeSO}_{4} \cdot 7 \mathrm{H}_{2} \mathrm{O}$, $1.25 \mathrm{~g}$ EDTA-di-Na-salt per $250 \mathrm{ml}$ distilled water; solution 3: microelements $2.86 \mathrm{~g} \mathrm{H}_{3} \mathrm{BO}_{3}, 1.81 \mathrm{~g} \mathrm{MnCl}_{2} \cdot 4 \mathrm{H}_{2} \mathrm{O}, 0.08 \mathrm{~g} \mathrm{CuSO}_{4} \cdot 5 \mathrm{H}_{2} \mathrm{O}, 0.09 \mathrm{~g} \mathrm{H}_{2} \mathrm{MoO}_{4}$ $\mathrm{H}_{2} \mathrm{O}, 0.22 \mathrm{~g} \mathrm{ZnSO}_{4} \cdot 7 \mathrm{H}_{2} \mathrm{O}$; Hoagland's solution contains per 10 liters: 1 liter solution $1,6 \mathrm{ml}$ solution 2 and $10 \mathrm{ml}$ solution $3, \mathrm{pH} 6.5$ ). The jars were covered with sterile tinfoil to facilitate bacterial colonization and prevent contamination and dispersion of the inoculated bacteria through the air. After the seeds had germinated, perforations were made in the tinfoil and plants were allowed to grow through them over $21 \mathrm{~d}$ in a growth chamber (constant temperature of $22{ }^{\circ} \mathrm{C}$, relative humidity $65 \%$, and $14 / 10 \mathrm{~h}$ light and dark cycle, PAR (photosynthetic active radiation) $165 \mu \mathrm{mol} / \mathrm{m}^{2} \mathrm{~s}$ ). The same procedure was used to inoculate L. luteus $L$. with the B. cepacia strains BU0072 and G4.

Recovery of endophytic bacteria. Plants were harvested after $21 \mathrm{~d}$. Roots and shoots were treated separately. Fresh root and shoot material was vigorously washed in distilled water for $5 \mathrm{~min}$, surface-sterilized for $5 \mathrm{~min}$ in a solution containing $1 \%$ active chloride (wt/vol, added as a $\mathrm{NaOCl}$ solution) supplemented with 1 droplet Tween 80 per $100 \mathrm{ml}$ solution and rinsed three times in sterile distilled water. A $100 \mu \mathrm{l}$ sample of the third rinsing water was plated on 869 medium to verify the efficiency of sterilization. After sterilization, the roots and shoots were macerated in $10 \mathrm{ml} 10 \mathrm{mM} \mathrm{MgSO}_{4}$ using a Polytron PT1200 mixer (Kinematica A6). Samples $(100 \mu \mathrm{l})$ were plated on different selective and nonselective media to test for the presence of the endophytes and their characteristics.

Toluene degradation and phytotoxicity tests on hydroponics. Three-week-old L. luteus L. plants (both controls and those inoculated with B. cepacia VM1330, BU0072 or G4) were used to evaluate the phytotoxicity of toluene and its in planta degradation. The lupine plants were carefully taken out of the jars and their roots were vigorously rinsed in sterile water to remove bacteria from the surface. Subsequently, plants were grown hydroponically, settled in a twocompartment glass cuvette system ( $29 \mathrm{~cm}$ high; $9 \mathrm{~cm}$ in diameter) (Fig. 1). To avoid gas exchange between the upper and lower compartments, they were separated by a glass plate, with an insertion through which the stem of the plant was introduced. Each cuvette contained one plant and the space around the stem was made gas-tight with a Polyfilla exterior mixture (Polyfilla), so that shoots in the upper compartment and roots in the lower compartment were completely separated, allowing no gas exchange between them, except through the stem. The upper compartment, the glass plate and the lower compartment were sealed with Apiezon (Apiezon Products M\&I Materials LTD). The lower compartment was filled with $300 \mathrm{ml}$ of sterile, half-strength Hoagland's solution. Different toluene concentrations of $0,100,500$, and $1,000 \mathrm{mg} / \mathrm{l}$ were added to the Hoagland's solution at the beginning of the experiment. The cuvettes with plants were placed in a growth chamber with constant temperature $22^{\circ} \mathrm{C}$ and $14 / 10$ hours light/dark cycle; photosynthetic active radiation $165 \mathrm{mmol} / \mathrm{m}^{2} \mathrm{~s}$. Each compartment was connected with a synthetic air source (Air Liquide) with an inflow of 1 liter per hour. The phytotoxic effects of toluene under the different conditions were examined by determining the increase in plant biomass after $4 \mathrm{~d}$.

We examined the effect of the different endophytic bacteria on toluene degradation and evapotranspiration using the following experimental setup. In the experiment where $100 \mathrm{mg} / \mathrm{l}$ toluene was added, two-serial linked Tenax traps (Capped Sample Tubes (Perkin Elmer) and Tenax 60/80 (Alltech)) were inserted in the outflow of each compartment to capture any transpired or volatilized toluene. The traps were changed regularly. A column filled with $\mathrm{CaCl}_{2}$ was installed between the cuvettes and the Tenax traps as a trap to prevent condensation of water in the Tenax traps. To optimize the Tenax adsorption capabilities, the traps were cooled with dry ice. The whole experiment ran for $96 \mathrm{~h}$, and toluene concentration in the traps was determined by GC-MS (Automatic thermal Desorption System ATD400, Auto System XL Gas Chromatograph, Turbo Mass Spectrometer, Perkin Elmer). All experiments were done in triplicate to allow statistical analysis of the data using ANOVA.

Toluene toxicity test under green house conditions. After 3 weeks of growth under the above conditions, control plants and lupine plants inoculated with B. cepacia strains VM1330, BU0072 and G4 were transferred into half-liter pots filled with a nonsterile sandy soil, irrigated with half-strength Hoagland's solution. Plants were allowed to stabilize for $3 \mathrm{~d}$. Subsequently, plants were irrigated every other day with half-strength Hoagland's solution to which toluene was added at concentrations of $0,100,250$ and $500 \mathrm{mg} / \mathrm{l}$. After two weeks plants were harvested and their biomass was determined. For each treatment five replicas were done.

\section{ACKNOWLEDGMENTS}

The European Commission under the Fifth Framework Program, Quality of Life supported this work by grant no. QLK3-2000-00164 entitled "ENDEGRADE." The work was also supported by Ford Motor Company (Genk Plant and the Environmental Quality Office Europe), which also provides experimental sites. We thank K. Germaine and E. Keogh for providing us with tomA specific primers, F. Tibaldi for statistic analysis of our data, D. Van Genechten for assisting in the conjugation experiments and J. Czech and R. Carleer for help with toluene analysis. Special thanks are due to M. Mergeay who interested us in the potential of endophytic bacteria. D.v.d.L. and S.T. are presently being supported by Laboratory Directed Research and Development funds at the Brookhaven National Laboratory under contract with the US Department of Energy. This paper is dedicated to the memory of Licy Oeyen.

\section{COMPETING INTERESTS STATEMENT}

The authors declare that they have no competing financial interests.

Received 27 January; accepted 19 February 2004

Published online at http://www. nature.com/naturebiotechnology/

1. Schnoor, L.J., Licht, A.L., McCutchon, C.S., Wolfe, N.L. \& Carreira, H.L. Phytoremediation of organic and nutrient contaminants. Environ. Sci. Technol. 29, 318A-323A (1995)

2. Harvey P.J. et al. Phytoremediation of polyaromatic hydrocarbons, anilines and phenols. Environ. Sci. Pollut. Res. Int. 9, 29-47 (2002).

3. Cunningham, S.D. \& Berti, W.B. Remediation of contaminated soils with green plants: an overview. In Vitro Cell. Dev. Biol. 29, 207-212 (1993).

4. Trapp, S., Köhler, A., Larsen, L.C., Zambrano, K.C. \& Karlson, U. Phytotoxicity of fresh and weathered diesel and gasoline to willow and poplar trees. J. Soils Sed. 1, 71-76 (2001). 


\section{ARTICLES}

5. Trapp, S., Zambrano, K.C., Kusk, K.O. \& Karlson, U. A phytotoxicity test using transpiration of willows. Arch. Environ. Contam. Toxicol. 39, 154-160 (2000).

6. Doucete, W.J. et al. Phytoremediation of dissolved phase trichloroethylene using mature vegetation. in Bioremediation and Phytoremediation: Chlorinated and Recalcitrant Compounds (eds. Wickraamanayakee, G.B. \& Hinchee, R.E.) 251-256 (Battelle Press, Columbus, Ohio, USA, 1998).

7. Van der Lelie, D., Schwitzguebel, J.-P., Glass, D.J., Vangronsveld, J. \& Baker A Assessing phytoremediation's progress in the United States and Europe. Environ. Sci. Technol. 35, 446A-452A (2001).

8. Schwitzguebel, J.-P., van der Lelie, D., Glass, D.J., Vangronsveld, J. \& Baker A. Phytoremediation: European and American trends, successes, obstacles and needs. J. Soil Sed. 2, 91-99(2002).

9. Ma, X. \& Burken, J.G. TCE diffusion to the atmosphere in phytoremediation applications. Environ. Sci. Technol. 37, 2534-2539 (2003).

10. Burken, J.G. \& Schnoor, J.L. Distribution and volatilization of organic compounds following uptake by hybrid poplar trees. Int. J. Phytorem. 1, 139-151 (1999).

11. Misaghi, I.J. \& Donndelinger, C.R. Endophytic bacteria in symptom free cotton plants. Phytopathol. 80, 808-811 (1990).

12. James, K. \& Olivares, F.L. Infection and colonization of sugar cane and other Graminaceous plants by endophytic diazotrophs. Crit. Rev. Plant Sci. 17, 77-119 (1997).

13. Lodewyckx, C. et al. Endophytic bacteria and their potential applications. Crit. Rev. Plant Sci. 21, 583-606 (2002).

14. Frommel, M.I., Nowak, J. \& Lazarovits, G. Growth enhancement and developmental modifications of in vitro grown potato (Solanum tuberosum ssp. Tuberosum) as affected by a nonfluorescent Pseudomonas sp. Plant Physiol. 96, 928-936 (1991).

15. Lodewyckx, C. et al. The effect of recombinant heavy metal resistant endophytic bacteria in heavy metal uptake by their host plant. Int. J. Phytorem. 3, 173-187 (2001)

16. Taghavi, S., Delanghe, H., Lodewyckx, C., Mergeay, M. \& van der Lelie, D. Nickelresistance-based minitransposons: new tools for genetic manipulation of environmental bacteria. Appl. Environ. Microbiol. 67, 1015-1019 (2001).
17. Reiter, B., Burgmann, H., Burg, K. \& Sessitsch, A. Endophytic nifH gene diversity in African sweet potato. Can. J. Microbiol. 49, 549-555 (2003).

18. Bent, E. \& Chanway, C.P. Potential for misidentification of a spore-forming Paenibacillus polymyxa isolate as an endophyte by using culture-based methods. Appl. Environ. Microbiol. 68, 4650-4652 (2002).

19. Elvira-Recuenco, M. \& van Vuurde, J.W. Natural incidence of endophytic bacteria in pea cultivars under field conditions. Can. J. Microbiol. 46, 1036-1041 (2000).

20. Heyrman, J. et al. Bacillus novalis sp. nov., Bacillus vireti sp. nov., Bacillus soli sp. nov., Bacillus bataviensis sp. nov. and Bacillus drentensis sp. nov., from the Drentse A grasslands. Int. J. Syst. Evol. Microbiol. 54 (Pt 1), 47-57 (2004).

21. Siciliano, S.D. et al. Selection of specific endophytic bacterial genotypes by plants in response to soil contamination. Appl. Environ. Microbiol. 67, 2469-2475 (2001).

22. Sharp R.R., Bryers J.D., Jones W.G. \& Shields, M.S. Activity and stability of a recombinant plasmid-borne TCE degradative pathway in suspended cultures. Biotechnol. Bioeng. 57, 287-296 (1998)

23. Shields, M.S. \& Reagin, M.J. Selection of a Pseudomonas cepacia strain constitutive for the degradation of trichloroethylene. Appl. Environ. Microbiol. 58, 3977-3983 (1992).

24. Germaine, K. et al. Colonization of poplar trees by gfp expressing bacterial endophytes. FEMS Microbiol. Ecol. in the press (2004).

25. McCrady, J., Mc Farlane, C. \& Lindstrom, F. The transport and affinity of substituted benzenes in soybean stems. J. Exp. Botany 38, 1875-1890 (1987).

26. Shields, M.S., Reagin, M.J., Gerger, R.R., Campbell, R. \& Somerville, C. TOM, a new aromatic degradative plasmid from Burkolderia (Pseudomonas) cepacia G4. Appl. Environ. Microbiol. 61, 1352-1356 (1995).

27. Schlegel, H.G., Kaltwasser, H. \& Gottschalk, G. Ein Sumbersverfahren zur Kultur wasserstoffoxidierender Bacterien: Wachstum physiologische Untersuchungen. Arch. Mikrobiol. 38, 205-222 (1961).

28. Mergeay, M., Nies, D., Schlegel, H.G., Gerits, J. \& Van Gijsegem, F. Alcaligens eutrophus $\mathrm{CH} 34$ is a facultative chemolithotroph with plasmid-bound resistance to heavy metals. J. Bacteriol. 162, 328-334 (1985). 